\title{
NGUYÊN NHÂN GÂY KHÒ KHÈ Ở TRẺ DƯớI 5 TUỔI TẠI KHOA NHI BỆNH VIỆN ĐA KHOA TÂM ANH
}

\section{TÓM TẮT}

Khò khè là một trong các triêu chứng về hô hấp thường gặp nhất ở trẻ em. Mục tiêuu của nghiên cứu là " Xác định một số nguyên nhân gây khò khè ở trẻ dưới 5 tuổi điều trị nội trú tại khoa Nhi - bệnh viện đa khoa Tâm Anh". Phương pháp nghiên cứu: Ṅghiên cứu mô tả cắt ngang ở 83 trẻ dưới 5 tuổi có triêuu chứng khò khè tại khoa Nhi bệnh viện đa khoa Tâm Anh từ tháng 7/2020 đến tháng 6/2021. Kết quả: Viêm tiểu phế quản và hen phế quản là 2 nguyên nhân thường gặp nhất gây khò khè, trong đó viêm tiểu phế quản chủ yếu gặp ở trẻ dưới 2 tuổi và triệu chứng khò khè thường xuất hiên lần đầu trước 12 tháng tuổi. Kiểu hình khò khè khởi phát muộn đa số được chẩn đoán là hen phế quản và thường là khò khè tái đi tái lại. Kết luận: Viêm tiểu phế quản và hen phế quản là 2 nguyên nhân thường gặp nhất gây khò khè ở trẻ dưới 5 tuổi, kiểu hình khởi phát khò khè có giá trị trong định hướng nguyên nhân gây khò khè.

Từ khóa: Khò khè, trẻ dưới 5 tuổi, nguyên nhân.

\section{SUMMARY}

CAUSES OF WHEEZING IN CHILDREN UNDER 5 YEARS OLD AT THE PEDIATRIC DEPARTMENT - TAM ANH GENERAL HOSPITAL

Wheezing is one of most common respiratory symptom in children. Objectives: To determine the causes of wheezing in children under 5 years old hospitalised at the Pediatric department - Tam Anh general hospital. Subjects and methods: A crosssectional study in 83 patients under 5 years old had wheezing symptoms admitted at the Pediatric department - Tam Anh hospital from July 2020 to June 2021. Results: Bronchiolitis and Asthma are the most common causes of wheezing in children under 5 years old, bronchiolitis mostly occur in children under 2 years old and wheezing symptom usually appear for the first time before 12 months old. Patients with wheezing occured lately (after 12months) and recurrent wheezing were diagnosis with asthma. Conclusion: Bronchiolitis and Asthma are the most common causes of wheezing in children under 5 years old, the phenotype of the first wheezing episode has value to determine the cause of wheezing.

Keywords: Wheezing, children under 5 years old, causes.

\section{I. ĐĂT VẤN ĐỀ}

Khò khè là một triệu chứng rất thường gặp ở

*Trường Đại học Y Hà Nọi

Chịu trách nhiệm chính: Phạm Đức Tuấn

Email: tuantk21ntt@gmail.com

Ngày nhận bài: 28.5.2021

Ngày phản biên khoa hoc: 28.7.2021

Ngày duyệt bài: 2.8.2021

\section{Phạm Đức Tuấn*, Nguyễn Thị Diệu Thúy*}

trẻ nhỏ, do nhiều nguyên nhân gây ra. Theo Martinez và cộng sự, khoảng $25-30 \%$ trẻ dưới 1 tuổi có ít nhất 1 lần khò khè, $40 \%$ trẻ dưới 3 tuổi có khò khè ít nhất 1 lần và đến 6 tuổi thì khoảng $50 \%$ trẻ em đã từng bị khò khè [1]. Ở trẻ nhỏ, khò khè dù là thoáng qua hay dai dẳng đều có thể nặng, nguy hiểm đòi hỏi chẩn đoán và điều trị kịp thời. Tuy nhiên, khò khè chỉ là một triệu chứng do nhiêu nguyên nhân khác nhau gây ra, mỗi nguyên nhân có đặc điểm lâm sàng và cận lâm sàng khác nhau. Những nguyên nhân thường gặp nhất bao gồm: viêm tiểu phế quản, hen phế quản, trào ngược dạ dày thực quản. Nguyên nhân ít phổ biến hơn bao gồm bất thường bẩm sinh đường thở, dị vật đường thở, và một số bệnh lý hiếm gặp khác [2]. Mối nguyên nhân có một kiểu hình, đăc điểm lâm sàng, cận lâm sàng khác nhau. Viêm tiểu phế quản là nguyên nhân gây khò khè thường gặp nhất đối với trẻ < 2 tuổi. Hen phế quản là vấn đề sức khỏe toàn cầu ảnh hưởng đến mọi lứa tuổi, khò khè trong bệnh hen phế quản thường là khò khè dai dẳng hoặc khò khè khởi phát muộn. Ngược lại, ở những bệnh lý bẩm sinh khò khè thường xuất hiện sớm sau sinh. Vì vậy nghiên cứu này được tiến hành với mục tiêu xác định một số nguyên nhân gây khò khè ở trẻ dưới 5 tuổi điều trị nội trú tại khoa Nhi - bệnh viện đa khoa Tâm Anh.

\section{II. ĐỐI TƯợNG VÀ PHƯƠNG PHÁP NGHIÊN CỨU}

\section{1. Đối tượng nghiên cứu}

Tiêu chuần lưa chon. Tất cả bênh nhân dưới 60 tháng tuối có triệu chứng khò khè điều trị nội trú tại khoa Nhi bệnh viện đa khoa Tâm Anh từ 01/07/2020 đến 30/06/2021.

Tiêu chuẩn loại trừ: Bệnh nhân khò khè có kèm các di chứng bênh lý thần kinh như bai não, di chứng sau viêm não. Gia đình bệnh nhân không đồng ý tham gia nghiên cứu.

\section{Phương pháp nghiên cứu}

Thời gian nghiên cứu: Từ tháng 7/2020 đến tháng 6/2021.

Địa điểm nghiên cứu: Khoa Nhi, bệnh viện đa khoa Tâm Anh.

Thiết kế nghiên cứu: Nghiên cứu mô tả cắt ngang

Cỡ mẫu: mẫu thuận tiện, gồm tất cả bệnh nhân đáp ứng tiêu chuẩn 
Quy trình nghiên cứu: Trê được khai thác thông tin chung, hỏi tiền sử, bệnh sử, khám lâm sàng và chỉ định một số xét nghiệm cận lâm sàng phù hợp theo nguyên nhân bác sĩ lâm sàng xác định khò khè sau khi hỏi bênh và khám lâm sàng. Chẩn đoán xác định nguyên nhân gây khò khè dựa vào hỏi bệnh, khám lâm sàng và cận lâm sàng.

3. Xử lí số liệu. Số liệu được xử lí theo thuật toán thống kê trển máy tính sử dụng phần mềm thống kê y học Stata 14.0. Sự khác biệt có ý nghĩa thống kể khi $p<0,05$.

4. Đạo đức nghiên cứu. Nghiên cứu được tiến hành sau khi thông qua đề cương tại trường đại học Y Hà Nội, Hội đồng khoa học, Hội đồng y đức bệnh viện đa khoa Tâm Anh. Bệnh nhân và gia đinh bệnh nhân được giải tích và tham gia nghiên cứu với tinh thần tự nguyện. Nghiên cứu không gây hại cho bệnh nhân. Mọi thông tin của bệnh nhân được bảo mật.

\section{KẾT QUẢ NGHIÊN CỨU}

Bảng 1. Đặc điểm chung của đôî tượng nghiên cứu.

\begin{tabular}{|c|c|c|c|}
\hline \multicolumn{2}{|c|}{ Đặc điếm } & $\mathbf{n}$ & $\mathbf{\%}$ \\
\hline \multirow{2}{*}{ Tuổi } & $<12$ tháng & 50 & 60,2 \\
\cline { 2 - 4 } & $12-24$ tháng & 23 & 27,7 \\
\cline { 2 - 4 } & $>24$ tháng & 10 & 12,1 \\
\hline \multirow{2}{*}{ Giới } & Nam & 54 & 65,1 \\
\cline { 2 - 4 } & Nữ & 29 & 34,9 \\
\hline Tiền sử dị ứng & Có & 30 & 36,1 \\
\cline { 2 - 4 } gia đình & Không & 53 & 63,9 \\
\hline Tiền sứ dị ứng & Có & 21 & 25,3 \\
\cline { 2 - 4 } bản thân & Không & 62 & 74,7 \\
\hline Sống trong & Có & 22 & 26,5 \\
\hline
\end{tabular}

\begin{tabular}{|c|c|c|c|}
\hline $\begin{array}{c}\text { môi trường có } \\
\text { người hút } \\
\text { thuốc lá }\end{array}$ & Không & 61 & 73,5 \\
\hline $\begin{array}{c}\text { Vật nuôi trong } \\
\text { nhà }\end{array}$ & Có & 17 & 20,5 \\
\cline { 2 - 4 } & Không & 66 & 79,5 \\
\hline Tiền sử đẻ non & Có & 7 & 8,4 \\
\cline { 2 - 4 } & Không & 76 & 91,6 \\
\hline $\begin{array}{c}\text { Nhẹ cân khi } \\
\text { sinh }\end{array}$ & Có & 7 & 8,4 \\
\cline { 2 - 4 } & Không & 76 & 91,6 \\
\hline
\end{tabular}

Nhận xét: Tuối trung bình của bệnh nhân trong nghiên cứu là 12,7 tháng, trẻ nhỏ nhất là 1 tháng và trẻ lớn nhất là 54 tháng tuổi. Nhóm dưới 12 tháng chiếm tỷ lê cao nhất 60,2\%, nhóm trên 24 tháng ít gặp nhất $12,1 \%$. Trẻ nam nhiều hơn trẻ nữ ở tất cả các nhóm tuổi, tỷ lệ nam/nũ là 1,9:1. Tỷ lệ trẻ có tiền sử gia đình mắc các bệnh dị ứng là $36,1 \%$. Tại thời điểm nghiên cứu, $25,3 \%$ trẻ có tiền sử mắc các bệnh dị ứng. Tỷ lệ trẻ sống trong gia đình có người hút thuốc lá là 26,5\%.

Bảng 2. Phân loại khò khè theo nhóm tuổi khởi phát

\begin{tabular}{|c|c|c|}
\hline Thời điếm khò khè & $\mathbf{n}$ & $\mathbf{\%}$ \\
\hline $\begin{array}{c}\text { Khò khè khởi phát sớm- } \\
\text { KKKPS (<12 tháng) }\end{array}$ & 69 & 83,1 \\
\hline $\begin{array}{c}\text { Khò khè khới phát trung } \\
\text { gian -KKKPTG(12-24 } \\
\text { tháng) }\end{array}$ & 10 & 12,1 \\
\hline $\begin{array}{c}\text { Khò khè khởi phát muộn- } \\
\text { KKKPM (> 24 tháng) }\end{array}$ & 4 & 4,8 \\
\hline Tống & $\mathbf{8 3}$ & $\mathbf{1 0 0 , 0}$ \\
\hline
\end{tabular}

Nhận xét: Trong nghiên cứu của chúng tôi, kiểu hình khò khè khởi phát sớm chiếm tỷ lệ cao nhất $83,1 \%$, tiếp đến là khò khè khởi phát trung gian chiếm $12,1 \%$, kiểu hình khò khè khởi phát muộn chiếm tỷ lệ thấp nhất là 4,8\%.

Bảng 3. Nguyên nhân khò khè theo tuổi khởi phát khò khè

\begin{tabular}{|c|c|c|c|c|c|c|}
\hline & \multicolumn{2}{|c|}{ KKKPS } & \multicolumn{2}{c|}{ KKKPTG } & \multicolumn{2}{c|}{ KKKPM } \\
\hline & $\mathbf{n}$ & $\mathbf{\%}$ & $\mathbf{n}$ & $\mathbf{\%}$ & $\mathbf{n}$ & $\mathbf{\%}$ \\
\hline Viêm tiếu phế quản & 61 & 88,4 & 6 & 60 & 0 & 0 \\
\hline Hen phế quản & 6 & 8,7 & 4 & 40 & 3 & 75 \\
\hline Nguyênn nhân khác & 2 & 2,9 & 0 & 0 & 1 & 25 \\
\hline
\end{tabular}

Nhận xét: Viêm tiểu phế quản là nguyên nhân thường gặp nhất trong kiểu hình khò khè khởi phát sớm chiếm $88,4 \%$. Trong nhóm khò khè khởi phát muộn $75 \%$ trẻ đủ tiêu chuẩn chẩn đoán hen phế quản, không có trẻ nào được chẩn đoán viêm tiểu phế quản.

Bảng 4. Đặc điểm lâm sàng theo nhóm tuổi khởi phát

\begin{tabular}{|c|c|c|c|}
\hline Triệu chứng & $\begin{array}{c}\text { Khò khè khởi phát } \\
\text { sớm }\end{array}$ & $\begin{array}{c}\text { Khò khè khởi phát } \\
\text { trung gian }\end{array}$ & $\begin{array}{c}\text { Khò khè khởi phát } \\
\text { muộn }\end{array}$ \\
\hline Ho & 94,2 & 100 & 100 \\
\hline Viêm long & 72,5 & 80 & 25 \\
\hline Rút lõm lồng ngực & 36,2 & 50 & 50 \\
\hline Sốt & 52,2 & 60 & 75 \\
\hline Nôn & 11,6 & 0 & 0 \\
\hline Số đợt khò khè & $2,26 \pm 2,03$ & $3,40 \pm 3,13$ & $4,75 \pm 2,75$ \\
\hline
\end{tabular}


Nhận xét: Tại thời điểm vào viện, ngoài triệu chứng khò khè, hầu hết bệnh nhân có triệu chứng ho, trong đó tất cả bệnh nhân khò khè khởi phát trung gian và khò khè khởi phát muộn đều có triêu chứng ho khi vào viên. Triệu chứng thường gặp khác là hội chứng viêm long đường hô hấp trên với tỷ lê $72 \%$. Số đợt khò khè trung bình của kiểu hình khò khè khởi phát sớm là 2,26 đợt, kiểu hình khò khè khởi phát trung gian là 3,4 đợt và của kiểu hình khò khè khởi phát muộn là 4,75 đơt. Số đơt khò khè của 3 kiểu hình là khác biệt có ý nghĩa thống kê với $p=0,0299$.

\section{Bảng 5. Đăc điểm cân lâm sàng theo nhóm tuổi khởi phát}

\begin{tabular}{|c|c|c|c|}
\hline & $\begin{array}{c}\text { Khò khè khởi phát } \\
\text { sớm }\end{array}$ & $\begin{array}{c}\text { Khò khè khởi phát } \\
\text { trung gian }\end{array}$ & $\begin{array}{c}\text { Khò khè khởi phát } \\
\text { muộn }\end{array}$ \\
\hline $\mathrm{n}$ & 69 & 10 & 4 \\
\hline Bạch câuu ưa acid & $0,22 \pm 0,25$ & $0,18 \pm 0,22$ & $0,33 \pm 0,29$ \\
\hline Xquang & $11 / 46$ & $2 / 8$ & $1 / 3$ \\
\hline RSV & $16 / 59$ & $1 / 8$ & $0 / 1$ \\
\hline Cấy dịch tỵ hầu & $18 / 43$ & $3 / 7$ & $0 / 1$ \\
\hline
\end{tabular}

Nhận xét: Số lượng bạch cầu ưa acid trung bình của kiểu hình khò khè khởi phát muộn cao hơn so với kiểu hình khò khè khởi phát sớm $(0,33$ so với 0,22$)$, tuy nhiên sự khác biệt này không có ý nghĩa thống kê với $p=0,7416$. Về xét nghiệm vi sinh, RSV test nhanh được thực hiện trên 68 bệnh nhân, trong đó kiểu hình khò khè khởi phát sớm có tỷ lệ RSV dương tính cao nhất $27,1 \%$, kiểu hình khò khè khởi phát trung gian có tỷ lệ RSV dương tính là $12,5 \%$. Cây dịch tỵ hầu được thực hiện trên 51 bệnh nhân với tỷ lệ dương tính là $41,1 \%$.

\section{BÀN LUÂ̂N}

Từ tháng $7 / 2020$ đến tháng $6 / 2021$, có 83 trẻ có triệu chứng khò khè đủ tiêu chuẩn được mời tham gia nghiên cứu. Tuổi trung bình của bệnh nhân là 12,7 tháng, trẻ nhỏ tuổi nhất là 1 tháng và trẻ lớn tuổi nhất là 54 tháng. Kết quả nghiên cứu này tương tự như kết quả nghiên cứu của Patra và cộng sự (2011) [3] tuổi khởi phát khò khè trung bình là 10,8 $\pm 5,24$ tháng.

Nhóm dưới 12 tháng chiếm tỳ lệ cao nhất chiếm tỷ lệ $60,2 \%$, nhóm trên 24 tháng ít gặp nhất chiếm tỷ lệ 12,1\%, Trong nghiên cứu của Antonia Maria Rosa và cộng sự [4] cho thấy tỷ lệ khò khè của nhóm 12 tháng tuổi là 43,2\%. Một nghiên cứu khác của Martinez và cộng sự (2004) [5] trên 6265 trẻ cho thấy 50\% trẻ biểu hiện triệu chứng khò khè trong năm đầu đời.

Trong nghiên cứu của chúng tôi, khò khè thường gặp ở trẻ nam hơn so với trẻ nữ với tỷ lê nam/nữ là $1,9 / 1$, kết quả này tương tự với nghiên cứu của Nguyễn Thị Hà (2013) [6] cho thấy số trẻ trai bị khò khè nhiều gấp 2 lần số trẻ gái. Nhiêu nghiên cứu khác cũng cho thấy tần suất khò khè ở trai cao hơn trẻ gấi. Guilbert (2004) [7] giả định rằng trẻ trai có mẫn cảm với các di nguyên đường hô hấp nhiều hơn so với trẻ gái $(p<0,03)$ nên thường tăng phản ứng đường thở hơn so với trẻ gái.

Chúng tôi phân loại 3 kiểu hình khò khè dựa vào thời gian xuất hiện triệu chứng khò khè lần đầu tiên. Kiểu hình khò khè khởi phát sớm khi triệu chứng khò khè xuất hiện trước 12 tháng, kiểu hình khò khè khởi phát trung gian khi triệu chứng khò khè xuất hiện từ 12 đến 24 tháng tuổi và kiểu hình khò khè khởi phát muộn khi triệu chứng khò khè xuất hiện sau 24 tháng. Kết quả nghiên cứu cho thấy khò khè khởi phát sớm chiếm tỷ lệ cao nhất $83,1 \%$, tiếp đến là khò khè khởi phát trung gian chiếm 12,1\%, kiểu hình khò khè khởi phát muộn chiếm tỳ lệ thấp nhất là $4,8 \%$. Kết quả nghiên cứu này tương tự với nghiên cứu của Nguyễn Thị Hà (2013) [6] cho thấy kiểu hình khò khè khởi phát sớm có tỷ lệ cao nhất, chiếm $74,5 \%$.

Trong kiểu hình khò khè khởi phát sớm, viêm tiểu phế quản là nguyên nhân thường gặp nhất chiếm $88,4 \%$, trong nhóm khò khè khởi phát muộn $75 \%$ trẻ đủ tiêu chuẩn chẩn đoán hen phế quản. Nghiên cứu của Nguyễn Thị Hiền (2015) [8] cho thấy trong kiểu hình khò khè khởi phát sớm, viêm tiểu phế quản cũng là nguyên nhân thường gặp nhất, chiếm tỷ lệ 57\%.

Số đợt khò khè trung bình của kiểu hình khò khè khởi phát sớm là 2,26 đợt, kiểu hình khò khè khởi phát trung gian là 3,4 đợt và kiểu hình khò khè khởi phát muộn là 4,75 đợt. Số đợt khò khè trung bình của 3 kiểu hình khác biệt có ý nghĩa thống kê với $p=0,0299$.

Tại thời điểm vào viện, ngoài triêu chứng khò khè, hầu hết bệnh nhân có triệu chứng ho, trong đó tất cả bệnh nhân khò khè khởi phát trung gian và khò khè khởi phát muộn đều có triệu chứng ho khi vào viện. Triệu chứng thường gắp khác là hội chứng viêm long đường hô hấp trền với tỷ lệ $72 \%$. Ngoài ra chúng ta có thể gặp một số triệu chứng khác như sốt, nôn, rút lõm lồng 
ngực. Trong 83 bệnh nhân trong nghiên cứu có $38,6 \%$ trẻ có biểu hiện khó thở và rút lõm lồng ngực khi nhập viện. Nôn cũng là một triệu chứng khá thường gặp chiếm $9,6 \%$, trong đó có 1 trẻ đủ tiêu chuẩn chẩn đoán trào ngược dạ dày thực quản.

Số lượng bạch cầu ưa acid trung bình của kiểu hình khò khè khởi phát muộn cao hơn so với kiểu hình khò khè khởi phát sớm $(0,33$ so với $0,22)$, tuy nhiên sự khác biệt này không có ý nghĩa thống kê với $p=0,7416$. Về xét nghiệm vi sinh, RSV test nhanh được thực hiện trên 68 bênh nhân, đây là virus thường găp nhất gây khò khè ở trẻ nhỏ. Kiểu hình khò khè khởi phát sớm có tỷ lệ RSV dương tính cao nhất $27,1 \%$, kiểu hình khò khè khởi phát trung gian có tỷ lế RSV dương tính là $12,5 \%$. Cãy dịch ty hầu được thực hiện trên 51 bệnh nhân với tỷ lệ dương tính là $41,1 \%$, trong đó những vi khuẩn thường gặp nhất là Streptococcus pneumoniae, Moraxella catarrhalis, Haemophilus influenza.

\section{KẾT LUÂNN}

Viêm tiểu phế quản và hen phế quản là 2 nguyên nhân thường gặp nhất gây khò khè ở trẻ dưới 5 tuổi, trong đó viềm tiểu phế quản chủ yếu gặp ở trẻ dưới 2 tuổi và thường là kiểu hình khè khò khởi phát sớm. Số đợt khò khè trung bình của 3 kiểu hình khò khè khác biệt rõ rệt. Kiểu hình khò khè khởi phát muộn thường là khò khè tái đi tái lại và đa số được chẩn đoán là hen phế quản.

Lời cảm ơn. Chúng tôi xin chân thành cảm ơn bệnh nhi và gia đình trẻ đã tham gia, hợp tác tốt trong quá trình nghiên cứu. Xin cảm ơn Bệnh viện đa khoa Tâm Anh và đặc biệt là khoa Nhi đã tạo điều kiện thuận lợi để nhóm nghiên cứu có thể thu thập số liệu và hoàn thành nghiên cứu.

\section{TÀI LIỆ THAM KHẢO}

1. Martinez FD, Wright AL, Taussig LM, Holberg CJ, Halonen $\mathbf{M}$, Morgan WJ. Asthma and Wheezing in the First Six Years of Life. N Engl J Med. 1995;332(3):133-138.

2. Al-Shamrani A, Bagais $K$, Alenazi A, Alqwaiee M, Al-Harbi AS. Wheezing in children: Approaches to diagnosis and management. Int J Pediatr Adolesc Med. 2019;6(2):68-73.

3. Patra S, Singh V, Kumar P, Chandra J, Dutta A, Tripathi M. Demographic and Clinical Profile of Children Under Two Years of Age with Recurrent Wheezing. 2011;21:3.

4. Rosa AM, Jacobson Lda S, Botelho C, Ignotti E. Prevalence of wheezing and associated factors in children under 5 years of age in Cuiabá, Mato Grosso State, Brazil. Cad Saude Publica. 2013 Sep;29(9):1816-28.

5. Stein RT, Martinez FD. Asthma phenotypes in childhood: lessons from an epidemiological approach. Paediatr Respir Rev. 2004 Jun;5(2):155-61

6. Nguyê̂n Thị Hà (2013). Nghiên cứu nguyên nhân và đăc điểm lâm sàng theo nguyên nhân gây khò khè tái diến và/hoặc dai dẳng ở trẻ dưới 5 tuổi. Trường Đai học Y Hà Nối

7. Guilbert TW, Morgan Wj, Zeiger RS et al. Atopic characteristics of children with recurrent wheezing at high risk for the development of childhood asthma. J Allergy Clin Immunol. 2004 Dec;114(6):1282-7.

8. Nguyến Thị Hiên (2015). Nghiên cứu ñguyên nhân khò khè ở trẻ dưới 5 tuổi tại khoa Miễn dịch - Dị ứng khớp bệnh viện Nhi Trung Ương. Trường Đại học Y Hà Nội.

\section{ĐÁNH GIÁ KẾT QUẢ PHẪU THUÂTT ĐIỀU TRI UNG THƯ ĐẠI TRÀNG SIGMA}

\section{TÓM TẮT}

Mục tiêu nghiên cứu: Đánh giá kết quả phẫu thuật điều trị ung thư đại tràng sigma tại bệnh viện $\mathrm{K}$ từ 10/2015 đến tháng 7/2016. Đối tượng và phương pháp nghiên cứu: Nghiên cứu mô tả cắt ngang, hồi cứu kết hợp tiến cứu trên55 bệnh nhân ung thư đại tràng sigma được phẫu thuât tại bênh viên $\mathrm{K}$ tù̀ 10/2015-7/2016. Kết quả: Phẫu thuật mở chiếm

\footnotetext{
${ }^{1}$ Trường Đại học Y Hà Nội

${ }^{2}$ Bềnh viện $K$

Chịu trách nhiệm chính: Trịnh Lê Huy

Email: trinhlehuy@hmu.edu.vn

Ngày nhận bài: 2.6.2021

Ngày phản biên khoa hoc: 19.7.2021

Ngày duyệt bài: 2.8.2021
}

\section{Trịnh Lê Huy ${ }^{1}$, Mai Tiến Đạt ${ }^{2}$}

$81.8 \%$, nội soi chiếm $18.2 \%$. Thời gian phẫu thuật trung bình chung là 128 phút, giữa mổ nọi soi và mổ mở không có sự khác biệt. Số lượng máu mất trung bình là $115 \mathrm{ml}$, mổ nôi soi mất ít máu hơn mổ mở. Thời gian có trung tiện trở lại trung bình 3.26 ngày, của mổ nội soi có thời gian ngẳn hơn so với của mổ mở. Thời gian hậu phẫu trung bình là 10.28 ngày, mổ nội soi có thời gian ngắn hơn so với mổ mở. Mổ nội soi và mổ mở không có khác biệt về số lượng hạch trung bình vét được và tỷ lệ vét được từ 12 hạch trở lên. Kết luận: Phẫu thuật nội soi cho thấy hiệu quả phấu thuật cũng như độ an toàn tương đương mổ mở trong khi cải thiện chất lượng çuộc sống và giảm nguy cơ một số biến chứng sau mổ nên cần được áp dụng rộng rãi cho bệnh nhân ung thư đại tràngsigma.

Tư khóa: Ung thư đại tràng Sigma, phẫu thuật. 